\title{
Change of Pain, Lumbar Sagittal Alignment and Multifidus after Sling Exercise Therapy for Patients with Chronic Low Back Pain
}

\author{
Seung Jin Park', Ji Hyun Moon², Yun A Shin ${ }^{3}$ \\ ${ }^{1}$ Major in Exercise Physiology, Department of Physical Education, Graduate School, Dankook University, Cheonan; ${ }^{2}$ Major in Principle of Athletic \\ Training, Department of Kinesiology and Medical Science, Graduate School, Dankook University, Cheonan; ${ }^{3}$ Department Prescription \& \\ Rehabilitation of Exercise, Dankook University, Cheonan, Korea
}

Purpose: This study examined the effects of sling exercise therapy on vertebral alignment, VAS, muscle activity, and multifidus of patients with chronic low back pain.

Methods: Simple random sampling was used to divide the patients $(n=116)$ into the sling exercise therapy group (SETG) and conservative physical therapy group (CPTG), with each group provided a intervention program in 3 sessions a week for 12 weeks. The lumbar lordosis angle (LLA), lumbar intervertebral disc angle (LIVDA) for vertebral alignment, lumbar muscle activity, and multifidus atrophy were measured before and after the intervention.

Results: SETG showed significant changes in LLA, LIVDA of rate of change (delta score), and in relieving pain. The right-left balance gap for the lumbar dynamic muscle activity decreased after the intervention. The SETG showed significant changes in the grade of lumbar multifidus atrophy.

Conclusion: The sling exercise therapy program is an effective exercise therapy method on vertebral alignment, muscle activity, recovery from multifidus atrophy, and pain relief for patients with chronic low back pain.

Keywords: Sling exercise therapy, Low back pain, Sagittal alignment, Multifidus

\section{서 론}

1. 요통

요통은 성인 60-80\%에서 나타나는 일반적인 고통이며, 일상적인 활 동에 제한을 주는 것으로 알려져 있다. 또한 요통은 여러 가지 요인 중 감소되어진 신체활동을 포함한다.1,2 주 이상이 되어도 통증이 지 속되는 경우가 있는데 이를 만성요통이라고 한다. ${ }^{3}$

만성요통환자의 삶의 질은 낮고 기능장애도 심하며, 신경병증성 통증의 유병률이 상당히 높은 수준이다. ${ }^{4}$ 만성요통은 통증을 유발 하는 해부학적 구조물의 문제 및 척추와 골반의 움직임과 안정성에 영향을 미치는 체간 및 지체 근육의 약화 및 부조화 상태, 결체조직 의 구축으로 인한 비정상적인 생체역학 등 여러 가지 문제들이 총체 적으로 작용하여 발생된다. ${ }^{5}$

\section{2. 요추만곡}

정상적인 요추부의 전만은 외력에 대한 충격을 흡수하고 체간의 상 부로부터 오는 하중을 적절하게 분산시켜 주는 효과가 있다. ${ }^{6}$ 요추만 곡의 역학적 배열의 부조화는 요통과 관련성이 높고, 78 자세와 요통 간에는 상호 깊은 관련성이 있다.910 요추만곡의 변화는 척추에 가해 지는 과도한 힘으로 인하여 추간판의 변화 및 추체를 지지하는 인대 와 근육의 긴장을 유발하며 요천추 접합부의 전단력으로 요통을 일 으키게 된다. 따라서 요통환자들은 통증을 줄이기 위해 척추후관절 에 가해지는 압력과 요천추 접합부의 전단력을 최소화시키는 보상적 인 자세를 취하게 된다." 잘못된 자세와 움직임은 허리와 골반 주위 의 근육불균형을 만들게 되어 허리는 과도한 전만이 되고 이것은 골 반과 요추부주위에서 균형을 유지하던 복부 근육, 체간 신전근육, 고 관절 굴곡근육의 긴장도가 서로 달라지게 된다.12 


\section{3. 요통과 근긴장}

요통의 인자 중 많은 부분이 근육의 긴장 증가에 관여하고 통증-근 육경련-통증의 순환을 만들어 증상을 더욱 증가시키는 것으로 추정 하고 있다. ${ }^{13}$ 척추 안정화의 기계적 작용은 빠른 활성화 속도를 가진 척추 안정화 근육들과, ${ }^{14}$ 협력근육들의 조화로운 수축, 적당한 지구 력 ${ }^{15}$ 그리고 충분한 근력이다. ${ }^{16}$ 이러한 기계적 작용과 관계되는 근육 으로 척추 신전근은 심부 다열근과 천부 척추기립근으로 나뉘어지 며, 척추 신전근의 큰 시상면 동작, 전만의 유지, 요추 자세의 보존을 위하여 척추 신전근 길이와 크기가 영향을 미친다. ${ }^{17}$

뭇갈래근은 척추 간 안정장치로써 몸통을 굽힐 때 특히 회전력이 도입될 때 전범위에서 활동하며, ${ }^{18}$ 분절의 단단함과 동작 조절을 제공 하고, 척추분절에서 가까운 뭇갈래근은 빠른 수축 속도로 안정을 위 한 생역학을 제공한다. ${ }^{19}$ 그러나 요통환자에게서 나타나는 뭇갈래근 단면적 축소는 척추의 안정성과 진행성 척추 기능장애에 원인이 있 으며, 척추 주위 근육조직은 요통에 의해 위축된다고 하였다. ${ }^{20}$

\section{4. 요통의 중재}

일반적으로 급성요통은 보존적 치료(conservative treatment)에 의해 10-12주 이내에 치유가 가능하지만 급성요통에서 회복된 60-75\%의 환 자들은 2 년 이내에 재발되며 이들의 7-10\%는 만성요통으로 인한 신체 장애를 경험하고 있다. ${ }^{21}$ 요통의 감소와 재발방지를 목적으로 특정한 형태의 요부 운동방법들이 제시되고 있다. 그중 슬링운동은 불안정한 지면을 제공함과 동시에 근신경계를 자극하여 이완운동, 가동범위 증 가, 견인, 근육조직 안정화 훈련, 감각-운동 통합훈련, 동적인 근육 가 동성 운동, 근력 강화운동, 근지구력 운동에 효과적이라고 보고되었 다. ${ }^{22,23}$ 또한 체간근육의 기능향상과 심부근육 및 인대의 강화, 뭇갈래 근 강화운동으로 효과적이며 체간과 근위부 관절의 안정성을 증진시 키는 능동적인 치료법이라고 하였다. ${ }^{24,25}$ 이와 같이, 최근까지 슬링운 동과 관련하여 요부안정화운동 방법의 일환이나 요통환자의 운동치 료 및 효과에 관한 고찰의 자료, 그리고 근육의 활성도 및 근력에 미치 는 영향들을 다루고 있다. ${ }^{26,27}$ 척추정렬에 대한 연구는 척추질환 및 외 상환자의 치료 시 기준을 위한 요추분절 및 운동범위 연구외 ${ }^{28}$ 성인척
추변형에서 수술의 긍정적인 결과를 위해 골반입사각을 참조한 요추 전만각의 정상인의 각도에 유사하게 회복시키는 것의 중요성 등이 보 고되고 있다. ${ }^{29}$ 그러나 요통과 밀접한 척추정렬과 뭇갈래근 근위축 변 화에 대한 슬링운동의 연구는 다양하게 이루어지지 않고 있다.

따라서 이 연구는 슬링운동치료가 만성요통환자의 요추부 정렬의 변화와 통증정도 및 근활성도와 뭇갈래근 위축의 회복에 어떠한 영 향을 미치는지 관찰하고자 실시하였다.

\section{연구 방법}

\section{1. 연구대상}

이 연구의 대상은 2015년 3월 2일부터 2016년 9월 30일까지 한국의 경 기도 $\mathrm{S}$ 시 소재 $\mathrm{D}$ 병원을 내원한 요통이 3 개월 이상 지속되는 만성요 통환자를 대상으로 실시하였다. ${ }^{30}$ 만성요통환자 중 척추 수술을 받았 거나 골절, 종양, 염증, 대사성 질환 및 구조적 기형으로 인한 근골격 계 질환이 있는 환자를 제외하였다. 시각적 상사 척도 (visual analog scale, VAS) 3.4 이상을 보인 환자를 대상으로 실시하였다. ${ }^{31}$ 모든 대상 자에게 연구의 목적과 절차, 잠재적인 위험요인을 충분히 이해하고 연구에 참여의사를 밝힌 대상자는 총 150 명이었으나, 12 주간의 치료 와 평가 및 검사를 모두 참여한 최종 인원은 116 명이었다. 이 연구에 참여의사를 밝힌 모든 대상자를 단순무선표집추출법을 통해 분류 하였으며, 슬링운동집단 55명과 보존적 물리치료집단 61 명이 최종 분 석되었다. 단, 대상자는 연구실시 전 MRI를 통해 요추부 근위축 등급 을 확인한 후 대상자의 동질성을 확인하였다. 두 집단의 일반적 특성 은 다음과 같다(Table 1). 검정 결과 그룹 간의 통계적 유의한 차이는 나타나지 않았다. 또한 모든 대상자는 실험 전 윤리적인 부분을 고려 하여 동의서에 모두 서명함으로써 이 연구의 동의를 얻었다.

\section{2. 실험방법}

\section{1) 시각적 상사 척도}

요통지수는 시각적 상사 척도 (VAS)를 활용하여 통증지수를 측정하 였다. 이 지수는 통증이 없는 상태를 0 으로 하고 참을수 없는 통증을

Table 1. Physical characteristics of subjects

\begin{tabular}{|c|c|c|c|c|}
\hline \multirow{2}{*}{ Variables } & \multicolumn{2}{|c|}{ Group } & \multirow{2}{*}{$t(p)$} & \multirow{2}{*}{$\begin{array}{l}\text { Levene's } \\
\text { t (p) }\end{array}$} \\
\hline & SETG $(n=55)$ & CPTG $(n=61)$ & & \\
\hline Number (male/female) & $55(14 / 41)$ & $61(23 / 38)$ & $x^{2}=1.998(0.169)$ & \\
\hline Age (year) & $42.2 \pm 10.1$ & $41.8 \pm 10.6$ & $-0.223(0.824)$ & $0.367(0.546)$ \\
\hline Height (cm) & $164.0 \pm 6.5$ & $165.7 \pm 6.9$ & $1.377(0.171)$ & $1.936(0.167)$ \\
\hline Body weight (kg) & $59.9 \pm 8.4$ & $62.6 \pm 7.8$ & $1.988(0.051)$ & $0.054(0.817)$ \\
\hline BMI $\left(\mathrm{kg} / \mathrm{m}^{2}\right)$ & $22.2 \pm 1.9$ & $22.8 \pm 1.5$ & $1.968(0.052)$ & $1.458(0.230)$ \\
\hline VAS (score) & $6.1 \pm 1.0$ & $5.8 \pm 0.8$ & $-1.856(0.061)$ & $3.946(0.051)$ \\
\hline
\end{tabular}

SETG: Sling exercise therapy group, CPTG: conservative physical therapy group, BMl: body mass index, VAS: visual analog scale. 
10 으로 표현된 평행선 위에 환자가 자각하는 통증의 정도를 사전과 사후(12주 후)에 1회씩 직접 표기하도록 하였다.22

\section{2) 요추부 정렬}

요천추부위에 대한 측면사진을 단순 방사선 촬영은 선 자세에서 촬
영하여 의료영상저장전송시스템 (picture archiving and communication system, PACS) 프로그램을 이용하여 요추전만각 (lumbar lordosis angle, LLA)은 제 1 요추와 제 5 요추의 추체 상연에서 그은 선에서 각각 수직이 되는 선을 그어 교차하는 곳의 각을 측정하였고, 요추추간판 각 (lumbar intervertebral disc angle, LIVDA)은 위 척추의 하단 골단판
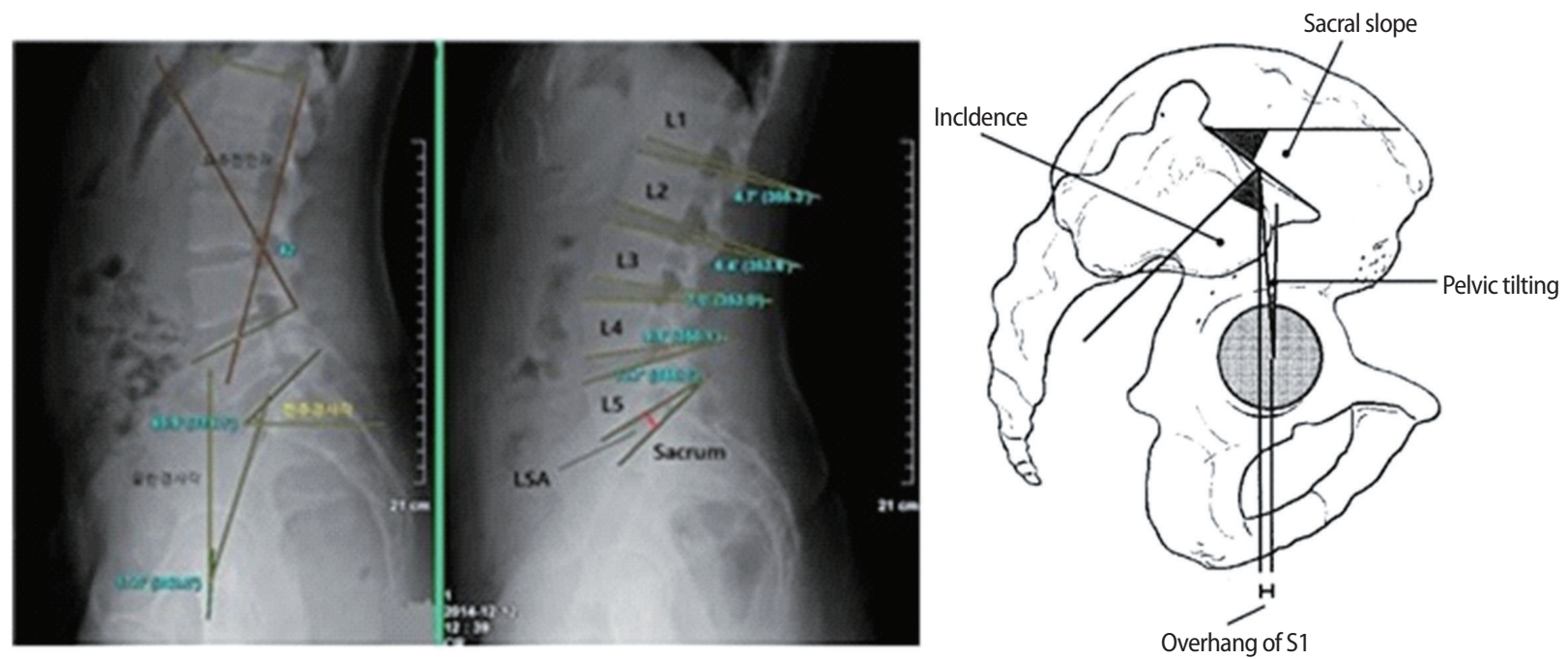

Figure 1. Roentgenography.
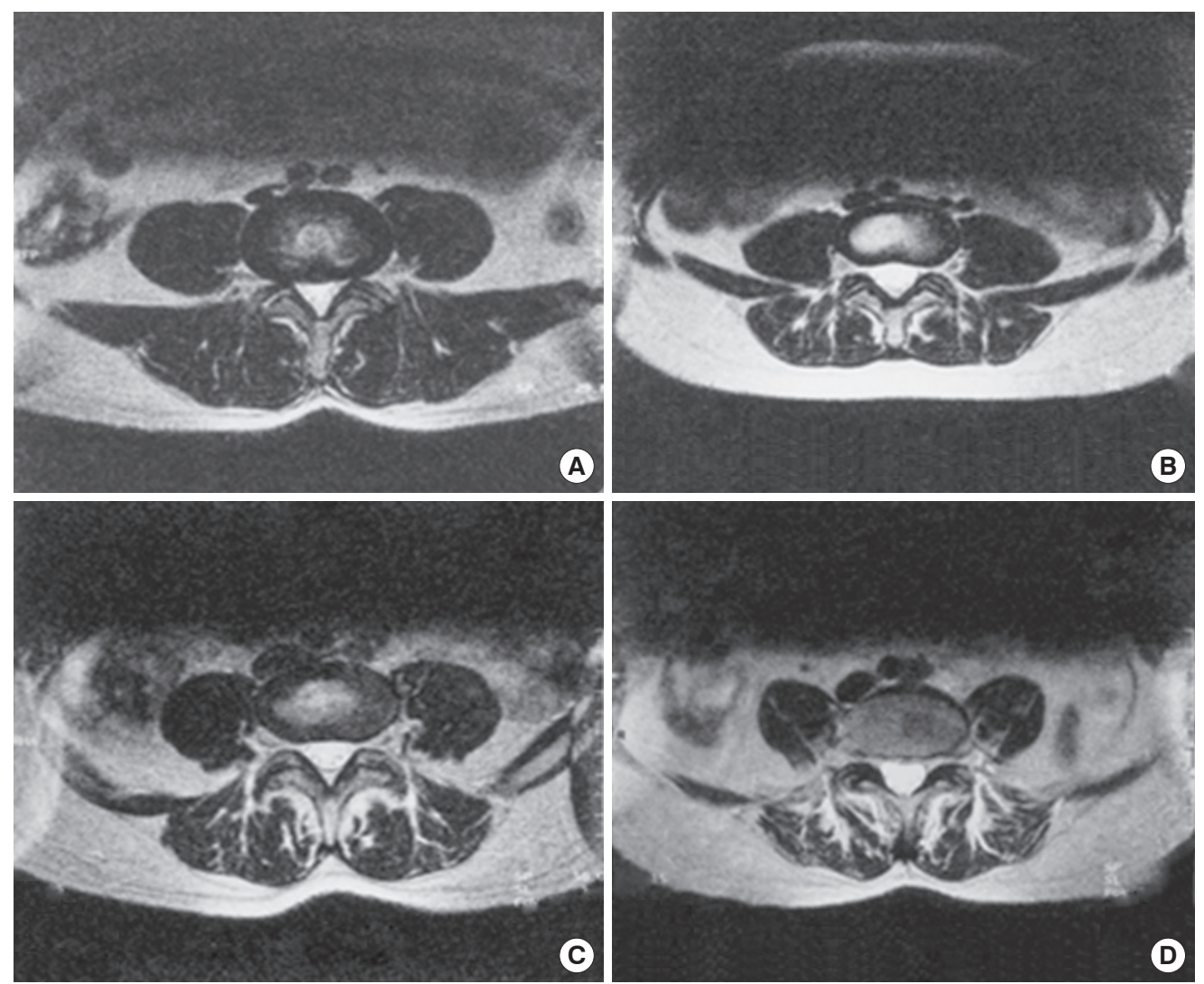

Figure 2. Graded the MF muscle atrophy. (A) Normal multifidus and erector spinae muscles, (B) Mild multifidus degeneration, (C) Moderate multifidus degeneration, (D) Severe multifidus and erector spinae muscles degeneration. 
을 이은선과 아래 척추의 상단 골단판을 이은선이 만나는 교차점의 각을 측정하였다(Figure 1) ${ }^{33,34}$

\section{3) 요추부 뭇갈래근 근위축 평가}

요추부 뭇갈래근의 시각적 평가는 자기공명영상(MRI) 장비(Magnetom symphony 1.5T, Siemens, Germany)를 이용하였으며, 대상자의 촬 영 자세는 앙와위(supine)자세에서 무릎밑에 쿠션을 받치고 슬관절 을 $25^{\circ}$ 굴곡시킨 상태로 제4-5번 요추부위를 촬영하였다. 요추 4-5번 부위의 종단면(axial) 영상을 획득하여 측정 프로그램인 컴퓨터영상 저장 및 전송 프로그램인 PACS를 이용하여 분석하였다. 시각적 뭇갈 래근 근위축정도 측정의 3 단계 방법은 측정이 용이하고 실제 근육크 기의 감소와도 연관성이 높으며 관찰자 간의 일치율이 높은 방법을 사용하였다. Mild 등급의 근위축은 지방이 섬유조직의 다열근 체적 의 $10 \%$ 미만으로 대체된 것, moderate 등급의 근위축은 지방이 섬유 조직의 뭇갈래근 체적의 $50 \%$ 미만으로 대체된 것, severe 등급의 근위 축은 지방이 섬유조직의 뭇갈래근 체적의 $50 \%$ 이상으로 대체된 것 으로 정의한다(Figure 2). 각 등급은 정의된 각 등급의 영상을 대상자 의 영상과 대조하여 평가하였다. ${ }^{35}$

\section{4) 뭇갈래근의 표면 근활성도(surface electromyography, SEMG) 측정}

근활성도 측정은 Myovision EMG 3000 (PMI/Myovision, San Carlos, $\mathrm{CA}$ )을 사용하였다. 이 장비는 25-500 Hz band pass filter를 사용하며, 결과에 대한 오차를 줄이기 위해 wideband filter를 사용하였다. 검사 의 범위는 0.08 에서 $200 \mu \mathrm{V}$ 사이이다. 검사 시 일회용 self-adhesive $2 \mathrm{Cm}$ $\mathrm{Ag} / \mathrm{Agcl}$ 전극을 사용한다. 알코올로 검사부위의 피부를 닦아주고, 검 사부위를 제모하였다. 정전기를 방지하기 위해 antistatic spray (PBI

Table 2. Sling exercise therapy program

\begin{tabular}{|c|c|c|}
\hline \multicolumn{3}{|c|}{ 슬링운동치료집단(n=55) } \\
\hline \multirow[t]{3}{*}{ 준비운동(10분) } & \multicolumn{2}{|c|}{ 1. 체간-골반의 정상적 정렬 조절 및 견인 } \\
\hline & \multicolumn{2}{|c|}{ 2. 체간-골반의 측방굴곡(추운동) } \\
\hline & \multicolumn{2}{|c|}{ 3. 슬링장비의 도르래를 이용한 하지 교차운동 } \\
\hline \multirow[t]{6}{*}{ 본 운동(35분) } & \multicolumn{2}{|c|}{ 1. 체간-골반의 견인 및 측방굴곡 운동 } \\
\hline & \multicolumn{2}{|c|}{ 2. 체간-골반의 회전 운동 } \\
\hline & \multicolumn{2}{|c|}{ 3. 골반의 전·후방 경사 운동 } \\
\hline & \multicolumn{2}{|c|}{ 4. 체간 및 고관절의 신전운동(교각운동) } \\
\hline & \multicolumn{2}{|c|}{ 5. 슬관절, 고관절, 체간의 신전/굴곡 동시 운동 } \\
\hline & \multicolumn{2}{|c|}{ 6. 복와위, 측와위 플랭크 운동 } \\
\hline \multirow[t]{6}{*}{ 정리운동(5분) } & \multicolumn{2}{|c|}{ 1. 체간-골반의 측방굴곡(추운동) } \\
\hline & 반복횟수 & $10-20$ \\
\hline & 세트 & $3-5$ \\
\hline & 운동 강도 & RPE: $10-14$ \\
\hline & 운동속도 & 중간속도 \\
\hline & 휴식시간 & 동작 간 10초 \\
\hline
\end{tabular}

Myovision)를 사용하였다. Data processing은 signal을 digitally rectified 와 low pass filtered를 통해 time-arranged amplitude로 계산한다. sEMG 제작사에서 제공한 4 channel EMG signal과 software는 IBM컴퓨터 (pentium,100 MHz)를 이용하여 기록되었다. 요추의 근활성도는 컴퓨 터를 통해 $\mu \mathrm{V}$ 로 기록되어지고, 동적 분석 데이터는 4 개의 전극을 좌우측 요추 제 1 번부터 요추 제 5 번의 뭇갈래근의 부위에 부착하고 체간 굴곡 3 차례의 평균 정점(average peak of 3 trials of flexion)과 체간의 재 신전의 정점 비율이 기록되어졌다. 동적 $\mathrm{sEMG}$ 는 3 회의 체간 굴곡과 재신전을 검사하는 방법으로, 116 명의 만성요통환자들은 같은 검사 방법으로 정적 그리고 동적 $\mathrm{sEMG}$ 검사를 시행하였으며, 각 환자에게 는 실험에 대해자세한 설명을 한 후 측정하였다.

\section{5) 중재방법}

슬링운동치료는 흔들리는 줄과 적당한 보조도구들을 이용한 수동 적인 치료와 능동적인 운동을 통해 신체적 장애를 개선하고 통증 조 절, 근력이나 지구력의 증가 등의 신체기능 향상을 얻어내고자 하는 치료접근방법이자 운동방법으로서 제시되었다. ${ }^{23}$ 이 연구에서는 슬 링운동치료 집단은 선행연구의 슬링운동프로그램22을 수정하여 적 용하였다(Table 2). 슬링운동치료집단은 슬링운동치료 프로그램 이외 에 보존적 물리치료는 시행하지 않았다. 보존적 물리치료집단의 중 재는 보존적 물리치료 프로그램만(Table 3)을 실시하였다. ${ }^{66}$

\section{6) 자료처리}

자료통계는 SPSS-PC for Windows (version 20.0, SPSS Inc., Chicago, IL, USA)로 분석하였다.

각 집단의 측정 항목별 기술통계를 실시하였으며, 각 집단의 집단 간 및 시기의 차이와 상호작용을 확인하기 위해 이원반복측정 분산 분석(two-way repeated measures ANOVA)을 사용하였다.

처치 후 집단 간 차이검증은 independent t-test를, 사전 사후 비교는 paired t-test를 실시하였다. 또한 각 집단 내 치료 전후의 변화율을 평 가하기 위해 $\%$ delta score $[\Delta \%=($ post-pre) $/$ pre $\times 100]$ 를 사용하였다. 사 전 사후 변화율의 효과크기를 계산하였다. ${ }^{37}$

집단 간 변화율의 비교를 위해 독립 t-검정(independent t-test)을 실 시하였다.

Table 3. Conservative physical therapy

\begin{tabular}{|c|c|c|}
\hline \multicolumn{3}{|c|}{ 보존적물리치료집단 $(n=61)$} \\
\hline 15-20분 & 온열 & $\begin{array}{l}\text { 요통발생부위의 온습포 또는 적외선 치료기를 이용하여 } \\
\text { 온열치료 적용 }\end{array}$ \\
\hline 15-20분 & 전기 & $\begin{array}{l}\text { 요통발생부위의 간섭전류 및 경피신경자극치료기를 이용 } \\
\text { 하여 전기치료 적용 }\end{array}$ \\
\hline 15-20분 & 감압 & 견인치료기를 이용하여 간헐적 골반견인치료 적용 \\
\hline 자율실시 & 자가운동지 & 골반의 전후방 경사운동 및 걷기 \\
\hline
\end{tabular}


이 연구의 모든 결과에 통계분석에 대한 유의수준은 $\alpha=0.05$ 로 설 정하였다.

\section{7) 연구의 제한점}

이 연구에 참여한 각각 집단의 대상자의 일상생활 및 여타시설에서 중재의 여부를 정확히 통제 및 확인할 수 없었다.

\section{결 과}

\section{1. 치료방법에 따른 요추 전만각과 통증정도의 변화}

12 주간 슬링운동치료와 보존적 물리치료 후 치료방법에 따른 요추전 만각과 통증정도의 변화는 다음과 같은 결과를 보였다(Table 4). 이 연 구의 결과 LLA는 시기에 따른 차이 $(\mathrm{p}<0.01)$ 와 상호작용효과 $(\mathrm{p}<0.01)$ 를 보였고, 슬링운동치료집단에서 유의한 변화율 $(\mathrm{p}<0.01)$ 과 치료효과가 나타났다 $(\mathrm{d}=-0.54) . \operatorname{VAS}$ 는 시기에 따른 차이가 나타났고 $(\mathrm{p}<0.001)$, 집
단 간 차이와 상호작용효과는 보이지 않았다. 그리고 변화량은 집단 간 차이를 보이지 않았으나, 유의미한 치료효과를 나타내었다 $(\mathrm{d}=0.36)$.

\section{2. 치료방법에 따른 요추 추간판각의 변화}

12 주간 슬링운동치료와 보존적 물리치료 후 치료방법에 따른 요추 추간판각의 변화는 다음과 같은 결과를 나타내었다(Table 5). 이 연구 의 결과 L1-L2 추간판각은 집단 간 유의한 차이가 나타났고 $(\mathrm{p}<0.05)$, 슬링운동치료집단이 보존적 물리치료집단보다 통계적으로 유의한 변화율과 치료효과를 보였다 $(\mathrm{p}<0.05, \mathrm{~d}=-0.47)$. L3-L4 추간판각은 시 기에 따른 유의한 차이가 나타났고 $(\mathrm{p}<0.05)$, 슬링운동치료집단이 유 의한 변화율 $(\mathrm{p}<0.01)$ 과 의미 있는 치료효과를 나타냈다 $(\mathrm{d}=-0.51)$. L4-L5 추간판각은 시기에 따른 유의한 차이와 $(\mathrm{p}<0.001)$ 상호작용효 과를 나타냈으며 $(\mathrm{p}<0.001)$, 슬링운동치료집단이 통계적으로 유의한 변화율 $(\mathrm{p}<0.01)$ 과 치료효과를 나타냈다 $(\mathrm{d}=-0.51)$.

Table 4. The changes of sagittal alignment of LLA and VAS (M $\pm S D)$

\begin{tabular}{|c|c|c|c|c|c|c|c|}
\hline Items & Groups (n) & Pre & Post & $\triangle \%$ & ES (d) & & $\mathrm{F}$ \\
\hline \multirow[t]{3}{*}{ VAS (score) } & SETG & $6.09 \pm 0.87$ & $2.58 \pm 0.66$ & $-57.17 \pm 11.10$ & & G & 0.093 \\
\hline & & & & & 0.36 & T & $1,383.708^{* * *}$ \\
\hline & CPTG & $5.89 \pm 0.86$ & $2.72 \pm 0.61$ & $-53.03 \pm 11.48$ & & $\mathrm{G}^{*} \mathrm{~T}$ & 3.702 \\
\hline \multirow[t]{3}{*}{$\operatorname{LLA}\left({ }^{\circ}\right)$} & SETG & $20.45 \pm 9.93$ & $23.60 \pm 6.79$ & $43.56 \pm 101.18^{\# \#}$ & & G & 0.117 \\
\hline & & & & & -0.54 & T & $8.027^{* *}$ \\
\hline & CPTG & $21.57 \pm 10.67$ & $21.34 \pm 9.75$ & $4.15 \pm 29.53$ & & $\mathrm{G}^{*} \mathrm{~T}$ & $10.823^{* *}$ \\
\hline
\end{tabular}

SETG: Sling exercise therapy group, CPTG: conservative physical therapy group, G: group, T: time, G*T: group*time, VAS: visual analog scale, LLA: lumbar lordosis angle, ES (d): effect size Index of t-test on means for different delta score, small-0.20, medium-0.50, large-0.80 (Cohen, 1977).

${ }^{\# D}$ Different delta score by independent $\mathrm{t}$-test, ${ }^{\circ} \mathrm{p}<0.05,{ }^{, \#} \mathrm{p}<0.01$. ${ }^{*}$ Different score by two way repeated measures ANOVA, ${ }^{*} \mathrm{p}<0.05,{ }^{* *} \mathrm{p}<0.01,{ }^{* * *} \mathrm{p}<0.001$.

Table 5. The changes of sagittal alignment of LIVDA (M \pm SD)

\begin{tabular}{|c|c|c|c|c|c|c|c|}
\hline Items & Groups (n) & Pre & Post & $\triangle \%$ & ES (d) & & $\mathrm{F}$ \\
\hline \multirow[t]{3}{*}{$\mathrm{L} 1-\mathrm{L} 2\left(^{\circ}\right)$} & SETG & $4.75 \pm 2.43$ & $5.22 \pm 1.30$ & $48.06 \pm 102.28^{\#}$ & & G & $4.389^{*}$ \\
\hline & & & & & -0.47 & $\mathrm{~T}$ & 2.581 \\
\hline & CPTG & $5.61 \pm 2.02$ & $5.81 \pm 2.67$ & $11.49 \pm 48.31$ & & $\mathrm{G}^{*} \mathrm{~T}$ & 0.415 \\
\hline \multirow[t]{3}{*}{$\mathrm{L} 2-\mathrm{L} 3\left(^{\circ}\right)$} & SETG & $6.89 \pm 2.74$ & $6.70 \pm 1.76$ & $11.22 \pm 54.28$ & & G & 0.107 \\
\hline & & & & & -0.03 & $\mathrm{~T}$ & 0.129 \\
\hline & CPTG & $6.63 \pm 2.61$ & $6.69 \pm 2.44$ & $9.75 \pm 34.42$ & & $\mathrm{G}^{*} \mathrm{~T}$ & 0.457 \\
\hline \multirow[t]{3}{*}{ L3-L4 $\left(^{\circ}\right)$} & SETG & $8.53 \pm 2.85$ & $9.22 \pm 1.85$ & $17.18 \pm 37.14^{\# \#}$ & & G & 0.623 \\
\hline & & & & & -0.51 & $\mathrm{~T}$ & $3.750^{*}$ \\
\hline & CPTG & $8.50 \pm 3.05$ & $8.52 \pm 2.61$ & $2.85 \pm 15.80$ & & $\mathrm{G}^{*} \mathrm{~T}$ & 3.385 \\
\hline \multirow[t]{3}{*}{ L4-L5 $\left(^{\circ}\right)$} & SETG & $8.77 \pm 4.57$ & $10.88 \pm 3.03$ & $63.98 \pm 136.10^{\# \#}$ & & G & 0.023 \\
\hline & & & & & -0.51 & $T$ & $17.971^{\text {*** }}$ \\
\hline & CPTG & $9.92 \pm 4.28$ & $9.94 \pm 3.62$ & $12.47 \pm 50.09$ & & $\mathrm{G}^{*} \mathrm{~T}$ & $17.136^{* * *}$ \\
\hline \multirow[t]{3}{*}{$\operatorname{LSA}\left({ }^{\circ}\right)$} & SETG & $14.12 \pm 5.52$ & $14.54 \pm 2.87$ & $15.50 \pm 44.27$ & & G & 1.136 \\
\hline & & & & & -0.22 & $\mathrm{~T}$ & 3.017 \\
\hline & CPTG & $13.24 \pm 4.75$ & $13.78 \pm 4.06$ & $8.01 \pm 19.89$ & & $\mathrm{G}^{*} \mathrm{~T}$ & 0.047 \\
\hline
\end{tabular}

SETG: Sling exercise therapy group, CPTG: Conservative physical therapy group, G: Group, T: Time, G*T: Group*time, LSA: lumbosacral angle (level of LIVDA L5-S1), ES(d): effect size Index of t-test on means for different delta score, small-0.20, medium-0.50, large-0.80(Cohen, 1977), LIVDA: lumbar intervertebral disc angle. Level of lumbar inter vertebral disc angle: L1-L2, L2-L3, L3-L4, L4-L5.

${ }^{\# D}$ ifferent delta score by independent $t$-test, ${ }^{\#} p<0.05,{ }^{* \#} p<0.01$. * Different score by two way repeated measures ANOVA, ${ }^{*} p<0.05,{ }^{* *} p<0.01,{ }^{* * *} p<0.001$. 
Table 6 . The changes of dynamic muscle activity between group ( $\mathrm{M} \pm \mathrm{SD}$ )

\begin{tabular}{|c|c|c|c|c|c|c|}
\hline \multicolumn{2}{|c|}{ Groups (n) } & \multirow{2}{*}{$\frac{\text { Pre }}{24.94 \pm 12.75}$} & \multirow{2}{*}{$\frac{\text { Post }}{6.59 \pm 3.26}$} & \multirow{2}{*}{$\begin{array}{c}\triangle \% \\
-70.00 \pm 13.26^{\# \#}\end{array}$} & \multicolumn{2}{|r|}{$\mathrm{F}$} \\
\hline SETG & Left $(n=34)$ & & & & G & 0.54 \\
\hline & & & & & T & $176.937^{* * *}$ \\
\hline & Right $(n=21)$ & $26.86 \pm 11.33$ & $7.67 \pm 2.89$ & $-69.63 \pm 9.32^{\#}$ & $G^{*} T$ & 0.088 \\
\hline \multirow[t]{3}{*}{ CPTG } & Left $(n=36)$ & $24.28 \pm 12.71$ & $12.58 \pm 8.00$ & $-41.68 \pm 47.68$ & G & 0.057 \\
\hline & & & & & $\mathrm{T}$ & $104.162^{* * *}$ \\
\hline & Right $(n=25)$ & $23.00 \pm 13.99$ & $12.60 \pm 8.14$ & $-16.57 \pm 102.01$ & $\mathrm{G}^{*} \mathrm{~T}$ & 0.358 \\
\hline
\end{tabular}

SETG: Sling exercise therapy group, CPTG: conservative physical therapy group, G: group, T: time, G*T: group *time.

${ }^{\# D}$ Different delta score by independent $t$-test, ${ }^{\#} p<0.05,{ }^{* \#} p<0.01$. ${ }^{*}$ Different score by two way repeated measures ANOVA, ${ }^{*} p<0.05,{ }^{* *} p<0.01,{ }^{* * *} p<0.001$.

Table 7. The changes of multifidus muscle atrophy in lumbar region $(\mathrm{M} \pm \mathrm{SD})$

\begin{tabular}{|c|c|c|c|c|c|c|c|}
\hline Items & Groups (n) & Grade & Pre (n) & Post (n) & $\triangle \%$ & & $\mathrm{~F}$ \\
\hline \multirow[t]{6}{*}{ MMAG } & SETG (55) & Mild & 20 & 40 & 100.00 & G & 0.093 \\
\hline & & Moderate & 31 & 14 & -54.84 & & \\
\hline & & Severe & 4 & 1 & -75.00 & $T$ & $31.757^{* * *}$ \\
\hline & CPTG (61) & Mild & 34 & 36 & 5.88 & & \\
\hline & & Moderate & 19 & 20 & 5.26 & $G^{*} T$ & $14.351^{* * *}$ \\
\hline & & Severe & 8 & 5 & -37.50 & & \\
\hline
\end{tabular}

SETG: Sling exercise therapy group, CPTG: conservative physical therapy group, MMAG: multifidus muscle atrophy grade, G: group, T: time, $\mathrm{G}^{\star} \mathrm{T}$ : group ${ }^{\star}$ time. ${ }^{\# D}$ Different delta score by independent $t-t e s t,{ }^{~} p<0.05,{ }^{* \#} p<0.01$. ${ }^{*}$ Different score by two way repeated measures ANOVA, ${ }^{*} p<0.05,{ }^{* *} p<0.01,{ }^{* * *} p<0.001$.

\section{3. 치료방법에 따른 요추부 동적 근활성도의 좌우 균형차이의 변화}

12 주간 슬링운동치료와 보존적 물리치료 후 치료방법에 따른 동적 근활성도의 좌우 균형차이의 변화는 다음과 같은 결과를 나타내었 다(Table 6). 치료방법에 따른 동적 근활성도의 좌우 균형차이의 변화 는 슬링운동치료집단에서 총 55 명 중 근활성도가 좌측으로 우세한 집단 $(\mathrm{n}=34)$ 에서 통계적으로 유의한 변화가 $(\mathrm{p}<0.01)$ 나타났고, 또한 우측으로 우세한 집단 $(\mathrm{n}=21)$ 에서도 유의한 변화가 $(\mathrm{p}<0.05)$ 나타났 다. 보존적 물리치료집단의 총 61 명 중 근활성도가 좌측으로 우세한 집단 $(\mathrm{n}=36)$ 과 우측으로 우세한 집단 $(\mathrm{n}=25)$ 모두 유의한 변화량을 보이지 않았다. 이원반복측정 분산분석 결과 슬링운동치료집단과 보존적 물리치료집단 모두에서 근활성도의 좌우 균형차이의 변화에 서 시기에 따른 통계적으로 유의한 차이가 나타났다 $(\mathrm{p}<0.001)$.

\section{4. 치료방법에 따른 요추부 뭇갈래근 근위축 등급의 변화}

12 주간 슬링운동치료와 보존적 물리치료 후 치료방법에 따른 요추 부 뭇갈래근 근위축 등급의 변화는 다음과 같은 결과를 나타냈었다 (Table 7).

뭇갈래근 근위축 등급의 변화량은 슬링운동치료집단에서 중재 전 20명이었던 mild 등급은 중재 후 40 명으로 $100 \%$ 증가하였고, moderate 등급은 중재 전 31명에서 11 명으로 $66.7 \%$, severe 등급은 4명에서 1 명으로 $75 \%$ 감소하였다. 그리고, 보존적 물리치료집단에서 34 명이었 던 mild 등급은 36 명으로 $5.8 \%$ 증가하였고, moderate 등급은 19 명에서 20 명으로 $5.26 \%$, severe 등급은 8 명에서 5 명으로 $37.5 \%$ 로 변화하였다.
이원반복측정 분산분석 결과 요추부 뭇갈래근 근위축 등급의 변화 는 집단 간 차이를 보아지 않았으나, 시기 간 통계적으로 유의한 차이 $(\mathrm{p}<0.001)$ 가 나타났고, 상호작용효과도 나타났다 $(\mathrm{p}<0.001)$.

고 찰

근골격계 질환의 재활훈련에 있어 치료적 운동(therapeutic exercise)은 근육의 기능향상을 위한 필수적인 접근방법으로 여겨지고 있다. 만 성, 급성 근골격계 질환을 지닌 환자의 대부분은 근위축과 근력 및 근지구력의 감소가 특징적으로 나타나므로 능동적 재활 운동프로 그램이 중요하다. ${ }^{19}$

이 연구의 슬링운동프로그램은 요통환자의 요부 안정화를 위해 실시하며 분절 간 안정성과 큰 움직임 간의 근육 협응패턴을 재교육 하는 것이 핵심인 운동이다. ${ }^{38}$ 특히 만성요통환자들은 요추전만각이 감소되어 있고, 이는 근육의 불균형과 보상작용을 야기하여 요통의 원인이 된다.7.8 요추전만과 요통의 관계는 오랫동안 논란이 되어 왔으 며 연구자마다 각각 다른 결과를 보고하고 있는데, Christie 등은 요 통은 요추전만의 증가와 관련이 있다고 보고하였으나 Tuzun 등 ${ }^{39}$ 은 요추전만각과 요통은 관련이 없다고 주장하였다. 이처럼 요통과 요 추전만각에 대한 관련성은 아직까지도 일치되지 않는 결과가 보고되 고 있다. Jackson과 McManus ${ }^{8}$ 의 연구에서는 요추전만각은 정상인이 $60.9^{\circ}$, 만성요통환자는 $56.3^{\circ}$ 로 요통환자군이 유의하게 낮았다고 보 고하였으며, 또 다른 연구에서는 남성 정상인의 요추전만각은 $38.9^{\circ}$, 
만성요통환자의 요추전만각은 $20.0^{\circ}$ 로 요통환자군이 유의하게 낮았 다고 보고하였다. ${ }^{40}$

이 연구에서 중재 전 만성요통환자 두 집단 모두 선행연구에서 제시 한 정상인의 요추전만각보다 요추전만각이 감소되어져 있었음을 알 수 있었다. 슬링운동치료집단에서 요추전만각은 평균 $20.45 \pm 9.93^{\circ}$ 에서 $23.60 \pm 6.79^{\circ}$ 로 유의하게 증가하였으나, 보존적 물리치료집단에서는 유 의한 차이가 나타나지 않았다. 요추추간판각의 변화는 각 수준에서 L1$\mathrm{L} 2$ ( $\mathrm{p}<0.05), \mathrm{L} 3-\mathrm{L} 4(\mathrm{p}<0.01), \mathrm{L} 4-\mathrm{L} 5$ ( $\mathrm{p}<0.01)$ 로 슬링운동치료집단에서 유 의한 변화가 나타났으며, L1-L2 (d=-0.47), L3-L4 ( $\mathrm{d}=-0.51), \mathrm{L} 4-\mathrm{L} 5$ ( $\mathrm{d}=$ $-0.51)$ 로 유의한 치료효과가 나타났다. 이러한 결과는 불안정한 지지면 에서의 운동이 체간과 하지의 근육활성화를 위해 효과적이고, ${ }^{41}$ 체간 과 근위부 관절주위의 근육 안정성의 증진, 그리고 심부복근과 척추관 절의 굴곡, 신전과 회전력을 강화시켜주는 결과를 보여준 선행연구 등 4 과 같이 이 연구의 슬링운동프로그램이 몸통근육의 기능향상과 근력 강화에 효과적인 방법으로 작용하였다고 사료된다. 또한 슬링운동치료 프로그램 적용 후 요추전만각과 골반정렬의 변화 그리고, 시기에 따른 의미 있는 통증의 감소 $(\mathrm{p}<0.001)$ 효과를 나타냈다고 할 수 있다.

또한, 동적 근활성도의 좌우 균형차이의 변화를 분석한 결과는 좌 측 또는 우측으로 우세하게 나타났던 좌우 균형의 차이가 슬링운동 치료집단에서 좌측에서 $\mathrm{p}<0.01$, 우측에서 $\mathrm{p}<0.05$ 으로 균형의 차이 가 감소하는 통계적으로 의미 있는 변화가 나타났다. 보존적 물리치 료집단에서는 통계적으로 유의한 변화가 나타나지 않았다. 이원반복 측정 분산분석 결과 슬링운동치료와 보존적 물리치료 두 집단에서 중재 전 요추부 근활성도의 좌우 균형차이의 정도는 두 집단 간 차이 를 보이지 않았으나, 슬링운동치료집단에서 시기 간 통계적으로 유의 한 차이가 나타났다 $(\mathrm{p}<0.001)$. 이는 만성요통환자에서 요추부의 근 활성도는 좌우 균형의 차이가 크게 존재한다는 것을 의미하고, 중재 후 두 집단에서 모두 좌우 근활성도의 차이가 감소되는 결과를 가져 왔으나 특히 슬링운동치료 집단에서 요추부의 좌우 근활성도의 균 형차이가 감소되었다는 것을 의미한다.

선행연구에서 슬링운동은 다양한 축의 변화를 이용하기 때문에 국소근육의 변화와 근력강화에 더 효과적인 영향을 주는 것으로 보 고되었다. ${ }^{723}$ 또한 통증의 감소와 함께 척추세움근, 속배빗근, 배곧은 근의 근활성도가 현저하게 변화하고, 체간근육의 기능향상과 근력강 화, 그리고 짧은 시간 내에 심부근육과 인대를 강화시키는 효과가 있 는 것으로 보고되었다. ${ }^{24,25,42}$ 따라서 이 연구의 요추부 근활성도의 좌 우 차이의 변화는 요추부 분절의 기능적 움직임을 활성화시키기 위 한 슬링운동치료가 국소근육의 변화에 영향을 미쳤다고 사료된다.

요통의 감소와 뭇갈래근 단면적 증가를 위한 중재방법에 대한 선 행연구에서 만성 요통환자로 진단받은 환자들을 대상으로 치료 전 과 치료 12 주 후 요부근육의 횡단면적을 분석한 결과 슬링운동치료
를 실시한 집단에서 요부 근육 중 뭇갈래근, 큰허리근, 허리네모근, 척 주세움근의 횡단면적 증가와 통증 감소가 유의미하게 나타났다고 하였다. ${ }^{43}$ 치료방법에 따른 요추부 뭇갈래근 근위축 등급의 변화를 관찰한 이 연구에서는 슬링운동치료집단에서 사후 뭇갈래근 근위축 의 개선에 의미 있는 변화를 보였다. 슬링운동치료집단에서 사전의 mild 등급 $(\mathrm{n}=20)$ 과 비교하여 사후 mild 등급 $(\mathrm{n}=40)$ 의 $100 \%$ 의 증가 와 moderate 등급의 $54.84 \%$ 의 감소는 Kader 등 35 이 제시한 3 단계 시각 적 측정방법을 기준으로 할 때 $50 \%$ 미만의 뭇갈래근 근위축의 단계 (moderate)에서 10\% 미만의 뭇갈래근 근위축의 단계(mild)로 근위축 의 상태가 회복되었다는 것을 의미한다. 즉, 뭇갈래근의 근육량이 증 가된 결과로 제시할 수 있다. 이는 슬링운동치료프로그램이 선행연 구의43,44 결과와 같이 요추부 뭇갈래근의 단면적 회복과 근력증가에 영향을 미치고, 통증감소에 유의미한 변화를 보인 것으로 사료된다.

결과적으로 슬링운동치료는 통증감소와 함께 요추부 시상면상 정렬인 요추전만각과 추간판각, 그리고 요추부 근활성도의 좌우 차 이 및 뭇갈래근 위축의 회복에 긍정적인 영향을 주는 것으로 나타났 다. 따라서 만성요통환자의 능동적인 슬링운동치료프로그램의 수행 이 요추부 국소부위의 정상적인 근육동원능력을 효과적으로 향상 시킬 수 있고, 요추부정렬과 동적 근활성도의 좌우차이의 정화상화 및 다열근 근위축의 회복에 효과적인 중재방법으로 제시할 수 있을 것으로 사료된다.

향후 연구에서는 본 연구에서 제한점이었던 대상자에 대한 보다 엄격한 통제를 통하여 더 나은 재현성을 위한 연구가 이루어지길 기 대한다. 또한, 슬링운동치료의 정량화되어진 운동강도의 측정이 이 루어진다면 다향한 대상자에게 더 정확한 운동지도 및 치료가 가능 해질 것으로 사료된다.

\section{참고문헌}

1. Oh YT, Gwon HC. The effect of auriculotherapy for pain control in HIVLD with sciatica. J Kor Soc Phys Ther. 1999;11(3):45-55.

2. Moon DC, Kown YS, Song YJ et al. Change of lumbar lordosis according to different heel heights in normal adults and patients with HNP. J Kor Soc Phys Ther. 2001;13(2):467-75.

3. Wheeler AH. Diagnosis and management of low back pain and sciatica. Am Fam Physician. 1995;52(5):1333-41.

4. Kim JH, Lee CS, Suk KS et al. Prevalence of neuropathic pain and patient-reported outcomes in Korean adults with chronic low back pain. J Korean Soc Spine Surg. 2016;23(S1):S8-10.

5. Chung SG. Rehabilitative treatments of chronic low back pain. Journal of the Korean Medical Association. 2007;50(6):494-506.

6. Christie HJ, Kumar S, Warren SA. Postural aberrations in low back pain. Arch Phys Med Rehabil. 1995;76(3):218-24.

7. Oh JS, Park JS, Kim SY et al. Comparison of muscle activity during a push-up on a suspension sling and a fixed support. J Kor Soc Phys Ther. 
2003;10(3):29-40.

8. Jackson RP, McManus AC. Radiographic analysis of sagittal plane alignment and balance in standing volunteers and patients with low back pain matched for age, sex, and size: a prospective controlled clinical study. Spine. 1994;19(14):1611-8.

9. Barrey C, Jund J, Perrin G et al. Spinopelvic alignment of patients with degenerative spondylolisthesis. Neurosurgery. 2007;61(5):981-6.

10. During J, Goudfrooij H, Keessen W et al. Toward standards for posture: postural characteristics of the lower back system in normal and pathologic conditions. Spine. 1985;10(1):83-7.

11. Dunlop RB, Adams MA, Hutton WC. Disc space narrowing and the lumbar facet joints. J Bone Joint Surg Br. 1984;66(5):706-10.

12. Radziszewski KR. Physical exercise in treatment of patients with lumbar discopathy. Ortop Traumatol Rehabil. 2007;9(1):98-106.

13. Cobb CR, Urban RT, Luekens CA et al. Electrical activity in muscle pain. Am J Phys Med. 1975;54(2):80-7.

14. Liebenson C. Chiropractic rehabilitation in the small clinic setting. Advances in Chiropractic. 1994;1:267-302.

15. Richardson CA, Jull GA. Muscle control-pain control. What exercises would you prescribe? Man Ther. 1995;1(1):2-10.

16. Janda V, Frank C, Liebenson C. Evaluation of muscular imbalance. Rehabilitation of the spine: a practitioner's manual. 1996;6:97-112.

17. Norris CM. Spinal stabilization: 3. Stabilization mechanisms of the lumbar spine. J Physio. 1995;81(2):72-9.

18. Wilke HJ, Wolf S, Claes LE et al. Stability increase of the lumbar spine with different muscle groups: a biomechanical in vitro study. Spine. 1995;20(2):192-7.

19. Hides JA, Richardson CA, Jull GA. Multifidus muscle recovery is not automatic after resolution of acute, first-episode low back pain. Spine. 1996;21(23):2763-9.

20. Lee DJ, Stokes MJ, Taylor RJ et al. Electro and acoustic myography for noninvasive assessment of lumbar paraspinal muscle function. Eur J Appl Physiol Occup Physiol. 1992;64(3):199-203.

21. Jeon EY. Effects of the hand acupressure and lumbar strengthening exercise on women with lower back pain. Jounal of East-West Nursing Research. 2013;19(2):63-70.

22. Park SJ, Shin JY, Hwang R. Sling exercise effects on sagittal alignment of chronic low back pain patients. The Korean Journal of Physical Education. 2015;54(1):527-34.

23. Kirkesola G. Sling exercise therapy (SET): a total concept for exercise and active treatment of musculoskeletal disorders. Journal of Korean Academy of Orthopedic Manual Physical Therapy. 2001;7(1):87-106.

24. Park GD, Lee WJ, Park SJ. The effect of sling-exercise on lumbar back strength stabilization for lumbar hernia operation patients. Journal of Sport and Leisure Studies. 2005;25:339-52.

25. Stray-Pedersen JI, Magnussen R, Kuffel E et al. Sling exercise training improves balance, kicking velocity and torso stabilization strength in elite soccer players. Med Sci Sports Exerc. 2006;38(5):S243.

26. Kang HJ, An KO, Ok JS. Effects of Sling exercise and segmental stabilizing exercise on the pain and activation of the deep muscle after lumbar disectomy. Asian J Kinesiol. 2013;15(2):117-28.
27. Lee DK, Lee SY. The effects of Medx exercise and Sling exercise program on the lumbar trunk muscle strength of patients with lumbar disc hernia operation. Journal of Korean Academy of Orthopedic Manual Physical Therapy. 2006;12(2):33-4.

28. Kim DS, Kim YM, Choi ES et al. Shape and motion of each lumbar segment in normal Korean adults. J Korean Orthop Assoc. 2008;43(5):595600.

29. Cho KJ, Kim YT, Seo BH et al. Radiological evaluation and classification of adult spinal deformity. J Korean Orthop Assoc. 2016;51:1-8.

30. Parkkola R, Rytökoski U, Kormano M. Magnetic resonance imaging of the discs and trunk muscles in patients with chronic low back pain and healthy control subjects. Spine. 1993;18(7):830-6.

31. Kim JW, Lee MY. Validity evidences of VAS pain scale utilizing objective physical activity measures in middle-aged females with low-back pain. The Korean Journal of Measurement and Evaluation in Physical Education and Sports Science. 2013;15(2):29-39.

32. Huskisson EC. Measurement of pain. The Lancet. 1974;304(7889):112731.

33. Harrison DE, Harrison DD, Cailliet R et al. Radiographic analysis of lumbar lordosis: centroid, Cobb, TRALL, and Harrison posterior tangent methods. Spine. 2001;26(11):e235-42.

34. Mixter WJ, Barr JS. Rupture of the intervertebral disc with involvement of the spinal canal. N Engl J Med. 1964;21(1):78-81.

35. Kader DF, Wardlaw D, Smith FW. Correlation between the MRI changes in the lumbar multifidus muscles and leg pain. Clin Radiol. 2000;55(2): 145-9.

36. Park JY. Nonsurgical management of chronic low back pain. J Korean Med Assoc. 2007;50(6):507-22.

37. Cohen J. Statistical power analysis for the behavioral sciences. 2nd ed. New York, Routledge, 1988.

38. Steven VK, Bouche KG, Mahieu NN et al. Trunk muscle activity in healthy subjects during bridging stabilization exercises. BMC Musculoskelet Disord. 2006;7(1):75.

39. Tüzün C, Yorulmaz I, Cindaş A et al. Low back pain and posture. Clin Rheumatol. 1999;18(4):308-12.

40. Jung YM, Choi JD. A comparison of lumbar lordotic curves between herniated nucleus pulposus pateints and normal subject using a flexible curve ruler. J Korean Soc Phys Ther. 2012;24(3):208-15.

41. Kim JH, Kim Y, Chung Y. The influence of an unstable surface on trunk and lower extremity muscle activities during variable bridging exercises. J Phys Ther Sci. 2014;26(4):521-3.

42. Park HS. The effects of Sling exercise to pain degree and muscle activity degree in low back pain patients. Journal of Sport and Leisure Studies. 2009;36(2):655-61.

43. Lee WH, Jeong SG, Park RJ. The effect of Sling exercise and conservative treatment on cross-section area change of lumbar muscles. J Korean Soc Phys Med. 2010;5(2):233-43.

44. Lee WJ. The effect of the lumbar back strength stabilization for chronic lumbargo patients by the Sling-exercise and Medx-training during 6weeks. The Korean Journal of Physical Education. 2005;44(5):485-92. 